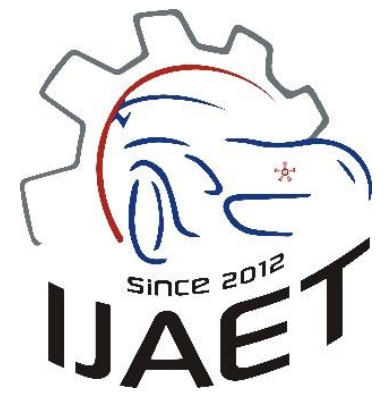

e-ISSN: 2146 - 9067

International Journal of Automotive

Engineering and Technologies

journal homepage:

https://dergipark.org.tr/en/pub/ijaet

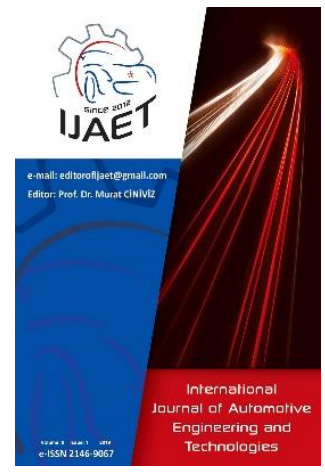

Original Research Article

\title{
The impacts of diesel and canola biodiesel fuels on noise emission on diesel engines
}

\author{
Fatih Aydin ${ }^{1 *}$ \\ ${ }^{1}$ Necmettin Erbakan University, Ereğli Faculty of Engineering and Natural Sciences Konya/Turkey
}

\section{ARTICLE INFO}

* Corresponding author

fatihaydin@erbakan.edu.tr

Received: May 31, 2019

Accepted: Oct 11, 2019

Published by Editorial Board Members of IJAET

(C) This article is distributed by Turk Journal Park System under the CC 4.0 terms and conditions.

\begin{abstract}
In this study, biodiesel was produced by converting canola oil to biodiesel by transesterification method. The obtained canola biodiesel $\left(\mathrm{B}_{100}\right)$ and diesel fuel $\left(D_{100}\right)$ were tested in a single-cylinder, four-stroke, water-cooled diesel engine to investigate noise emissions. In each fuel, the engine was operated under full load and as a result of the tests, noise values were measured at a distance of 50 $\mathrm{cm}$ from the four different points of the test engine and compared with the use of diesel fuel. During the noise emission measurements, the engine was brought to the test conditions in TS 1231 standard and the data were taken. The experiment values have complied with TS EN 590 for diesel fuel and TS EN 14214 for canola biodiesel.

As a result of the experiments, it was determined that $\mathrm{B}_{100}$ fuel was the ideal fuel type regarding noise emissions.

Keywords: ICE, Noise, Biodiesel, Diesel
\end{abstract}

\section{Introduction}

Vibration and noise are the most important problems of diesel engines, and these are a result of the combustion phenomenon occurring in diesel engines. One of the most important results of the vibration is material fatigue [1,2]. A large part of the vibration and noise are caused by the engines and exhaust system in vehicles large part of the vibrations becoming in engines are occurring from components such as variable gas forces acting on the pistons, inertia imbalance of moving and rotating parts and valve mechanism. Physical effects such as material fatigue, heating, friction, and impacts caused by vibrations are the result of deformations in the parts of the vehicle. Vibration measurements are widely used to characterize the combustion and monitor the engine operating conditions $[3,4]$.
Due to environmental policies, noise emissions for vehicles using all kinds of fuel are carefully examined [5]. One of the performance parameters most influenced by the fuel type is the engine noise [6]. Engine vibration causing noise pollution is another important result of biodiesel blends on environmental and human comfort [7]. Some of the biggest problems of diesel fuels are environmental pollution, noise, and vibration [8,9]. Diesel engines used fossilbased fuels have been causing air and sound pollution. It is predicted that non-renewable fossil fuels can be met the current demand of the market up to a maximum of 100 years [10]. Researchers emphasize that we need to develop alternative, cheap and environmentally friendly diesel fuels, and these studies will reduce dependence on fossil fuels due to limited fossil 
fuel resources [11]. Biodiesel as an alternative and the natural energy source is also ecofriendly, renewable, bio-degradable, non-toxic, technologically feasible, and energy efficient [12]. Biodiesel is an alternative diesel fuel produced from various vegetable and animal oils. Biodiesel properties may vary depending on the used oil source and the type of used alcohol in the production.

The properties of biodiesel lead to different ignition, combustion and emission characteristics [11]. Biodiesel creates a technologically feasible solution to environmental pollutions and petroleum-based fuels crises [13].

In this study, diesel (D100) and biodiesel (B100) fuels were tested in a four-stroke, single-cylinder, water-cooled diesel engine and noise emission characteristics were reached in the test results. During the noise emission measurements, the engine was brought to the test conditions in TS 1231 standard and the data were taken.

\section{Material and Methods}

Canola oil used in this study was obtained from the market. The biodiesel $\left(\mathrm{B}_{100}\right)$ of this oil was produced in the biodiesel reactor shown in Figure 1 at the Necmettin Erbakan University Ereğli Engineering and Natural Sciences Faculty, Energy Systems Engineering laboratory. $\mathrm{NaOH}$ was used as a catalyst, methyl alcohol was used as an alcohol and transesterification was used as a method in the production. Diesel fuel $\left(D_{100}\right)$ was obtained from BP Petroleum Company. Table 1 shows the technical specifications of the Super Star brand diesel engine used in the experiments. Transesterification reaction scheme is seen in figure 1 .

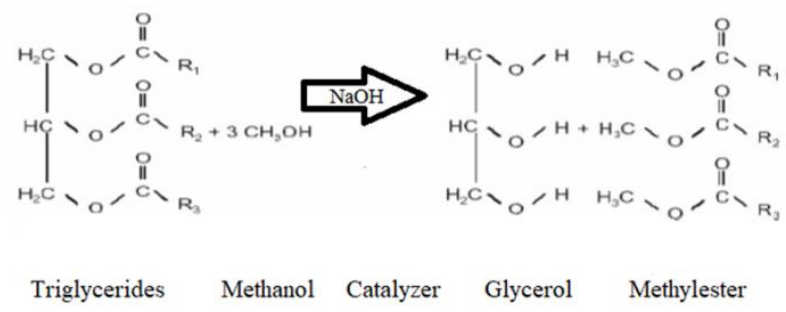

Fig. 1. Transesterification reaction of triglyceride with methanol [17]

The production of biodiesel takes six stages. These; transesterification by mixing catalyst and alcohol, reaction, separation, washing, drying and storage [18]

Necmettin Erbakan University Ereğli Engineering and Natural Sciences Faculty, Energy Systems Engineering Laboratory to produce biodiesel from canola crude oil is given below.

- Canola oil is added to the reactor; in the reactor, the oil was heated to $55^{\circ} \mathrm{C}$, which has the appropriate reaction temperature (best ester yield). The temperature was kept constant by the thermostat during the reaction. The crude oil was stirred for 1 hour to ensure a homogenous temperature.

- Methanol and $20 \%$ of canola oil were used as catalyst and sodium hydroxide at a rate of $3.5 \mathrm{~g} /$ liter to 1 liter.

- $\quad$ Methoxide was formed by mixing $100 \%$ of methanol and $100 \%$ of $\mathrm{NaOH}$ and sent to the oil in the reactor and stirred for one hour and at the end of one hour the device was switched off and the biodiesel was placed in the reactor for 8 hours.

- $\quad$ At the end of the waiting period, the glycerol was separated and the alcohol was evaporated by stirring again at $70{ }^{\circ} \mathrm{C}$ for 30 minutes.

- In the washing phase, $200 \mathrm{ml}$ of pure water for 1 liter of oil was heated to $50{ }^{\circ} \mathrm{C}$ and sent to the biodiesel by showering (sprinkling) method and put on hold for 8 hours.

At the end of the dwell time, settled water was removed and the remaining sample was stirred at $100{ }^{0} \mathrm{C}$ for 30 minutes and the remaining water was evaporated.

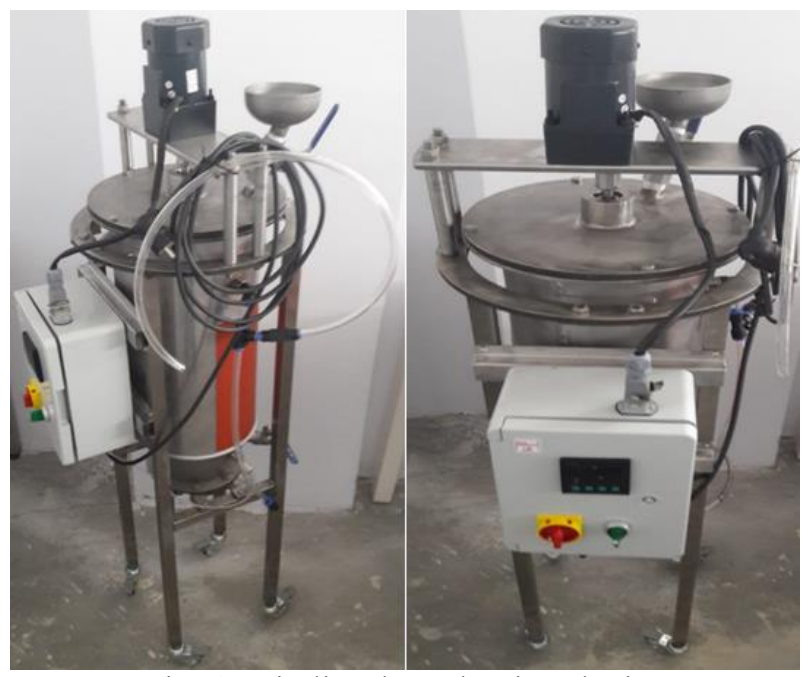

Fig. 2. Biodiesel production device

The study was carried out in six stages.

- Supply of canola oil, 
- Production of canola oil methyl ester (COME),

- Preparation of fuels in the form of $D_{100}$ and $\mathrm{B}_{100}$,

- Determination of fuel properties of fuels in the form of $\mathrm{D}_{100}$ and $\mathrm{B}_{100}$,

- Preparation of engine test and test environment,

Performing engine noise emission measurements.

Noise emission measurement tests were performed at Selçuk University, Agricultural Machinery and Technologies Engineering Department by using a hydraulic dynamometer and noise measurement device in the test engine whose specifications are given in Table 1.

Table 1. Technical specifications of the test engine

\begin{tabular}{lcc}
\multicolumn{1}{c}{$[14]$} & \\
\hline \multicolumn{1}{c}{ Specification } & Units & Value \\
\hline Working principle & --- & 4 stroke \\
Injection & --- & Direct injection \\
Cylinder Bore & $\mathrm{mm}$ & 108 \\
Cylinder Stroke & $\mathrm{mm}$ & 100 \\
Cylinder Number & --- & 1 \\
Cylinder Volume & $\mathrm{lt}$ & 0,92 \\
Compression Ratio & --- & $17: 1$ \\
Maximum Power & $\mathrm{HP}$ & 15 \\
Maximum Torque & $\mathrm{Nm}$ & 60 \\
Maximum Speed & $\mathrm{min}^{-1}$ & 2600 \\
Cooling System & --- & Water Cooling \\
Injection Advance & $\mathrm{kg} \cdot \mathrm{cm}^{-2}$ & 175 \\
\hline
\end{tabular}

The technical characteristics of the noise measurement device used in the experiments are given in Table 2 and the technical characteristics of the dynamometer are given in Table 3.
In measuring the noise level, a Smart Sensor AS 804 noise level meter with $30-130 \mathrm{~dB}$ measuring ranges and $\pm 1.5 \mathrm{Db}$ sensitivity was used. Specifications of Smart Sensor AS 804 noise level meter are given at Table 2.

Table 2. Noise level meter features [15]

\begin{tabular}{lcc}
\hline Smart Sensor AS 804 & Units & Value \\
\hline Frequency Ranges & $\mathrm{Hz}-\mathrm{KHz}$ & $31.5-8.5$ \\
Measuring Ranges & $\mathrm{dB}$ & $30-130$ \\
Accuracy & $\mathrm{dB}$ & \pm 1.5 \\
Resolution & $\mathrm{dB}$ & 0.1 \\
Digit & Digits & 5 \\
\hline
\end{tabular}

The fuel samples used in the experiments were prepared volumetrically. The mixture was homogenized by means of laboratory type mixer. Diesel (D100) and biodiesel (B100) fuel types are given in Table 4.

Table 3. Technical specifications of the hydraulic dynamometer [16]

\begin{tabular}{|l|c|c|}
\hline Type & Units & Value \\
\hline Operating Speed & $\mathrm{min}^{-1}$ & $0-7500$ \\
\hline Braking Torque Range & $\mathrm{Nm}$ & $0-1700$ \\
\hline Total Weight & $\mathrm{kgf}$ & 110 \\
\hline Torque Length & $\mathrm{mm}$ & 350 \\
\hline Trunk Weight & $\mathrm{kgf}$ & 45 \\
\hline Trunk Diameter & $\mathrm{mm}$ & 350 \\
\hline
\end{tabular}

\begin{tabular}{lcc}
\multicolumn{3}{l}{ Table 4. Compositions of test fuel } \\
\hline Test Fuels & Diesel & Biodiesel \\
\hline $\mathrm{B}_{100}$ & 0 & 100 \\
$\mathrm{D}_{100}$ & 100 & 0 \\
\hline
\end{tabular}

Test results for diesel and biodiesel fuels were described in Table 5. It is seen that the values in the table comply with TS EN 590 for diesel and TS EN 14214 for biodiesel.

Table 5. Analysis results for test fuels

\begin{tabular}{|c|c|c|c|c|c|c|}
\hline \multirow{2}{*}{ Characteristic Properties } & \multirow{2}{*}{ Units } & \multirow{2}{*}{$\mathrm{B}_{100}$} & \multirow{2}{*}{$\mathrm{D}_{100}$} & \multicolumn{2}{|c|}{ Limiting Values } & \multirow{2}{*}{ Method } \\
\hline & & & & Diesel & Biodiesel & \\
\hline Density $\left(15^{0} \mathrm{C}\right)$ & $\mathrm{g} / \mathrm{cm}^{3}$ & 0,882 & 0,833 & $0,82-0,84$ & $0,86-0,90$ & ASTM D 4052 \\
\hline Water Content & ppm & 489,57 & 36,45 & 200 & 500 & ASTM D 2709 \\
\hline Kinematic Viscosity $\left(40^{\circ} \mathrm{C}\right)$ & $\mathrm{mm}^{2} / \mathrm{s}$ & 4,395 & 2,985 & $2-4,5$ & $3,5-5$ & ASTM D 445 \\
\hline $\mathrm{PH}$ & -------- & 4,9 & 4,01 & - & - & ASTM D 5464 \\
\hline Flash Point & ${ }^{0} \mathrm{C}$ & 123 & 60 & 55 & 120 & ASTM D 93 \\
\hline Color & ASTM & 1,1 & 1,2 & & - & ASTM D 1500 \\
\hline Calorific Value & $\mathrm{Cal} / \mathrm{gr}$ & 9675 & 10418 & - & - & ASTM D 240 \\
\hline Cloud Point & ${ }^{0} \mathrm{C}$ & $-5,8$ & $-8,3$ & - & - & ASTM D 97 \\
\hline Pour Point & ${ }^{0} \mathrm{C}$ & $-9,2$ & $-15,2$ & 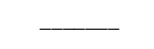 & - & ASTM D 97 \\
\hline Freezing Point & ${ }^{0} \mathrm{C}$ & $-12,2$ & -21 & 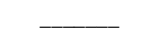 & - & ASTM D 97 \\
\hline CFPP & ${ }^{0} \mathrm{C}$ & -8 & -18 & -20 & -15 & ASTM D 6371 \\
\hline Copper Strip Corrosion & -------- & $1 \mathrm{a}$ & $1 \mathrm{a}$ & No: 1 & No: 1 & ASTM D 130 \\
\hline
\end{tabular}

\section{Result and Discussion}

\subsection{Noise emissions}

In the use of diesel and biodiesel fuels; in the tests performed on full load in different engine speeds, noise measurement points on the test engine are seen in Figure 3. 


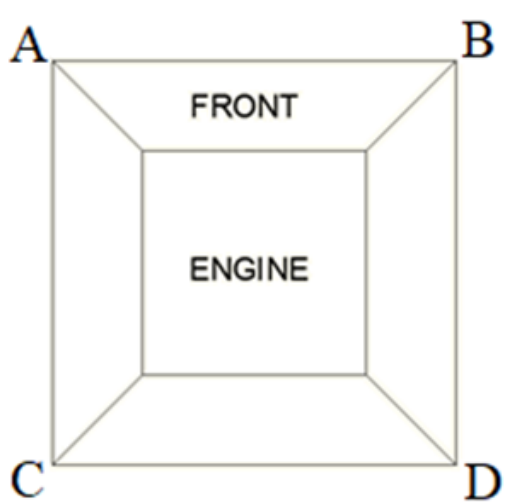

Fig. 3. Noise Measurement Points Made in the Test Engine

In Figure 4, depending on the engine speed, noise emission graphic that is measured in 50 -centimeter distance from A point is seen. When the graphic is examined, it is seen that according to $\mathrm{D}_{100}$ fuel noise emission values, a decrease of $0,10 \%$ occurred in the of $\mathrm{B}_{100}$ fuels in $2100 \mathrm{~min}^{-1}$ maximum engine power value.

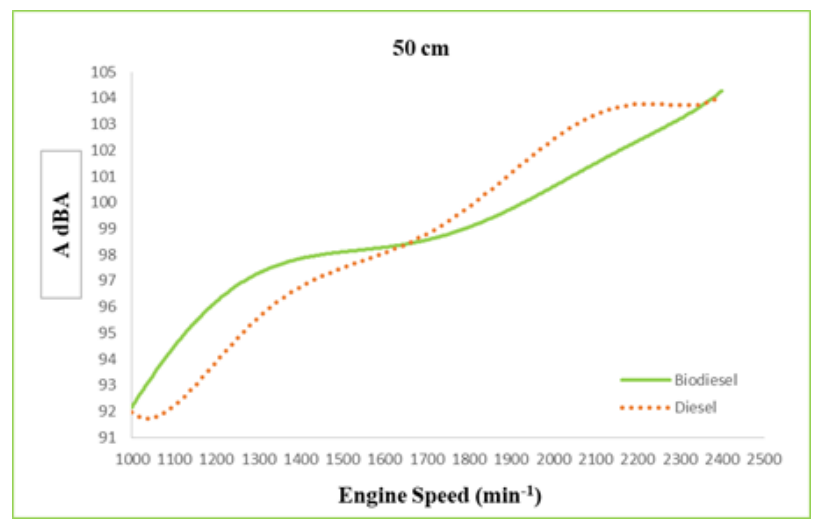

Fig. 4. Noise emissions in 50-centimeter distance from point $A$ of fuels depending on engine speed

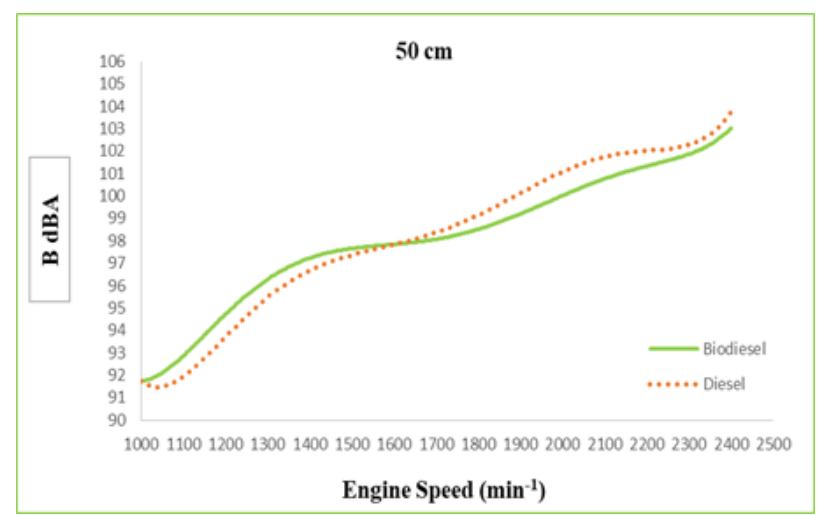

Fig. 5. Noise emissions in 50-centimeter distance from point $\mathrm{B}$ of fuels depending on engine speed

In Figure 5, depending on the engine speed, noise emission graphic that is measured in 50 -centimeter distance from B point is seen. When the graphic is examined it is seen that according to $\mathrm{D}_{100}$ fuel noise emission values, a decrease of $0.11 \%$ occurred in the of $\mathrm{B}_{100}$ fuels in $2100 \mathrm{~min}^{-1}$ maximum engine power value.

In Figure 6, depending on the engine speed, the fuels' noise emission graphic that is measured in 50-centimeter distance from the $\mathrm{C}$ point is seen. When the graphic is examined, it is seen that according to $\mathrm{D}_{100}$ fuel noise emission values, a decrease of $0,09 \%$ occurred in the of $\mathrm{B}_{100}$ in $2100 \mathrm{~min}^{-1}$ maximum engine power value.

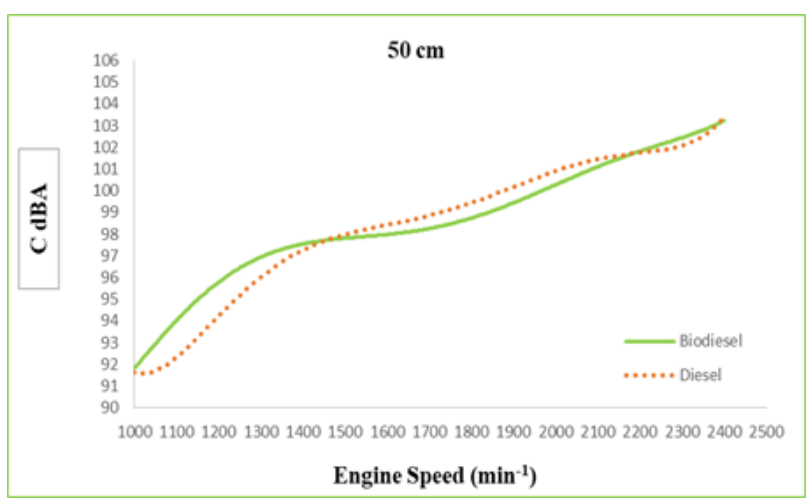

Fig. 6. Noise emissions in 50-centimeter distance from point $\mathrm{C}$ of fuels depending on engine speed

In Figure 7, depending on the engine speed, the fuels' noise emission graphic that is measured in 50-centimeter distance from the $\mathrm{D}$ point is seen. When the graphic is examined, it is seen that according to $D_{100}$ fuel noise emission values, a decrease of $0,12 \%$ occurred in the of $B_{100}$ in $2100 \mathrm{~min}^{-1}$ maximum engine power value.

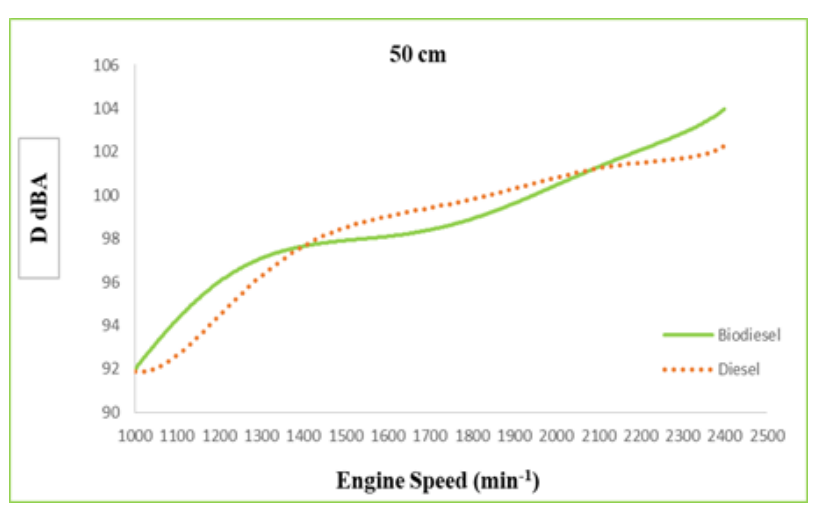

Fig. 7. Noise emissions in 50-centimeter distance from point $\mathrm{D}$ of fuels depending on engine speed

\section{Conclusions}

In this study, the tests were performed in a single cylinder, four stroke, water cooled diesel engine using biodiesel fuel $\left(\mathrm{B}_{100}\right)$ which was obtained from diesel fuel $\left(\mathrm{D}_{100}\right)$ and canola oil. The properties and noise emissions of these fuels were investigated and the data were presented with graphs. 
As a result of the experiments, $\mathrm{B}_{100}$ fuel was found to be the most suitable fuel in terms of noise emission. The reason why $\mathrm{B}_{100}$ fuel gives better results in noise emission values than $\mathrm{D}_{100}$ fuel is the low calorific value of canola biodiesel $\mathrm{B}_{100}$ compared to diesel fuel $\mathrm{D}_{100}$ and decrease in engine noise due to power decrease. Furthermore, since canola methyl ester has better lubrication properties than diesel fuel, noise emission is reduced when using $\mathrm{B}_{100}$ fuel [19].

Reduction of noise level in biodiesel tests will have a positive effect on biodiesel use in internal combustion diesel engines in the future.

\section{Abbreviation}

${ }^{\circ} \mathrm{C}$ : Celsius degree

ASTM: American Society for Testing and Materials

$\mathrm{B}_{100}$ : Canola Biodiesel

BP : British Petroleum

CFPP : Cold Filter Plugging Point

$\mathrm{cm}$ : Centimeter

COME: Canola Oil Methyl Ester

dB : Decibel

$\mathrm{D}_{100}$ : Diesel Fuel

EN : Europeane Norm

$\mathrm{g} / \mathrm{cm}^{3}:$ Gram / centimeter cube

HP : Horse power

$\mathrm{Hz}$ : Hertz

ICE : Internal Combustion Engine

$\mathrm{kg} / \mathrm{cm}^{2}:$ kilogram / square centimeter

$\mathrm{KHz}$ : kilohertz

lt : Liter

$\mathrm{mm}$ : Millimeter

$\mathrm{NaOH}$ : Sodium hydroxide

$\mathrm{Nm}$ : Newton meter

ppm : Parts-per million

TS : Turkish standard

\section{Acknowledgements}

This work was supported by the Scientific Research Council (BAP) of Necmettin Erbakan University.

\section{References}

1. Heidary, B., Ghobadian, B. and Taghizadeh, A., 2013, Vibration Analysis of a Small Diesel Engine Using Diesel-Biodiesel Fuel Blends, Agric Eng Int: CIGR Journal 2013; 15(3): 117-126.

2. Yıldırım, H., Özsezen A.N. and Çınar
A., 2018, Vibration and Noise Depending upon Engine Speed in a Diesel Engine Fueled with Biodiesel, The 6th European Conference on Renewable Energy Systems, İstanbul/Turkey 25-27 June 2018.

3. Liu, S., Gu, F. and Ball, A.,2006, Detection of Engine Valve Faults by Vibration Signals Measured on The Cylinder Head, Proc. IMechE 2006; 220: 379-386.

4. Lim, S. and Teong, L.K., 2010, Recent Trends, Opportunities and Challenges of Biodiesel in Malaysia: An Overview, Renewable and Sustainable Energy Reviews, 2010; 14(3): 938-954.

5. Ibarra D., Ramírez-Mendoza R. and Lopez E., 2017, Noise Emission from Alternative Fuel Vehicles: Study Case, Appl Acoust, 118: 58-65.

6. Siavash, N.K., Najafi, G., Hasanbeigi, R. and Ghobadian, B., 2015, Acoustic Analysis of a Single Cylinder Diesel Engine Using Biodiesel Fuel Blends. Energy Procedia 75: 893-899.

7. Çalık, A., 2018, Determination of Vibration Characteristics of a Compression Ignition Engine Operated by Hydrogen Enriched Diesel and Biodiesel Fuels, Fuel, 230: 355-358.

8. Taghizadeh-Alisaraei A., Ghobadian B., Tavakoli-Hashjin T. and Mohtasebi S.S., 2012, Vibration Analysis of a Diesel Engine Using Biodiesel and Petrodiesel Fuel Blends. Fuel, 102: 414-422.

9. Dal, H., Emiroğlu, A.O., Bilge, H. and Şen, M., 2018, Experimental Investigation of the Effects of Chicken and Turkey Biodiesel Blends on Diesel Engine Noise Emissions, International Journal of Environmental Science and Technology, https://doi.org/10.1007/s13762-018-1946-X.

10. Antoni, J., Daniere, J. and Guillet, F., 2002, Effective Vibration Analysis of IC Engines Using Cyclostationarity. Part 1: A Methodology for Condition Monitoring, Journal of Sound and Vibration, 2002; 257(5): 815-837. 11. Özsezen, A.N. and Canakçı, M., 2008, An Investigation of the Effect of Methyl Ester Produced from Waste Frying Oil on the Performance and Emissions of an IDI Diesel Engine, J. Fac. Eng. Arch. Gazi Univ., 2008; 23(2): 395-404.

12. Agarwal, A.K., 2007, Biofuels 
(Alcohols and Biodiesel) Applications as Fuels for Internal Combustion Engines. Prog Energy Combust Sci 33:233-271.

13. Refaat, A. A., 2010, Different Techniques for the Production of Biodiesel from Waste Vegetable Oil, Int J Environ Sci Technol, 7: 183-213.

14. Anonymous, 2009, Super Star Diesel Engine Operation and Maintenance Manual, İstanbul.

15. Anonymous, 2019, Smart Sensor AS 804 noise level meter [online], http://en.smartsensor.cn/products_detail/produc tId=243.html, Date of visit: [09.01.2019].

16. Anonymous, 2013, Hydraulic dynamometer [online], http://netfren.com/, Date of visit: [11.07.2013].

17. Niyet, M., 2009, Investigating the effect of biodiesel usage on the engine wear in diesel engines, Master Thesis, Dumlupınar University Graduate School of Natural and Applied Sciences, Kütahya, 15-16.

18. Eryılmaz, T., 2009, The Effect of the Different Mustard Oil Biodiesel Blending Ratios On Diesel Engines Performance, PhD Thesis, Selçuk University Graduate School of Natural and Applied Sciences, Konya, 89-90.

19. Oğuz, H., Düzcükoğlu, H. and Ekinci, Ş., 2011, The Investigation of Lubrication Properties Performance of Euro Diesel and Biodiesel. Tribology Transactions, 54(3), 449456. 